\title{
Variability of the growth parameters of the skipjack tuna (Katsuwonus pelamis) among areas in the eastern Atlantic: analysis from tagging data within a meta-analysis approach
}

\author{
Daniel Gaertner ${ }^{1}$, Alicia Delgado de Molina ${ }^{2}$, Javier Ariz ${ }^{2}$, Renaud Pianet ${ }^{3}$ and Jean Pierre Hallier ${ }^{4}$ \\ ${ }^{1}$ IRD, UR Thétis, CRH, BP 171, 34203 Sète Cedex, France \\ ${ }^{2}$ IEO, Centro Oceanográfico de Canarias, Apdo. de Correos 1373, 38080 Santa Cruz de Tenerife, Islas Canarias, Spain \\ ${ }^{3}$ IRD, US Osiris, CRH, BP 171, 34203 Sète Cedex, France \\ ${ }^{4}$ IRD, UR Thétis, and Regional Tuna Tagging Project - Indian Ocean (RTTP-IO), c/o IOTC PO Box 1011, Victoria, Seychelles
}

Received 19 February 2008; Accepted 15 May 2008

\begin{abstract}
In order to assess the latitudinal variability in growth of the eastern Atlantic skipjack (Katsuwonus pelamis), conventional tagging data collected by the International Commission of the Conservation of Atlantic Tunas (ICCAT) since the 1960s are reanalyzed using a modified version of the von Bertalanffy-Fabens growth model. An analysis of the latitudinal patterns of recaptures showed that the lowest mixing rate between northern and southern regions was evidenced at $10{ }^{\circ} \mathrm{N}$ Latitude. Since it is theoretically admitted that growth parameters $L_{\infty}$ and $K$ are negatively correlated, we substituted $L_{\infty}$ into the growth equation model by a simple bioenergetic function of $K$ fitted from existing studies on skipjack growth parameters. The likelihood for the meta-analysis of growth is combined with the likelihoods from the two regional tagging data with the aim of estimating simultaneously $K$ in both areas and to transfer adequately uncertainties associated with the different data sets. From this study, it was showed that fish inhabiting waters south of $10^{\circ} \mathrm{N}$ latitude can be expected to grow generally larger but at slower rate than in the North $\left(L_{\infty}=112.34 \mathrm{~cm}\right.$ vs. $89.38 \mathrm{~cm}$, and $K=0.14$ vs. 0.38 , respectively). Our results are consistent with the range of growth estimates obtained in the Atlantic Ocean and in different parts of the World's oceans. In contrast, the estimates of $L_{\infty}$ and $K$ done in the Senegalese region in the 1980s within the framework of the Skipjack Year Program, and traditionally applied by ICCAT, are not supported by the present study. The findings concerning the phenotypic plasticity exhibited by growth of skipjack among latitudinal regions suggest potential differences in fish population productivity and consequently that non conventional stock assessment methods such as catch-at size/growth transition matrix per region could be used to assess the responses of skipjack to exploitation.

Résumé - Variabilité de la croissance du listao (Katsuwonus pelamis) entre les secteurs de l'Atlantique Est : utilisation de données de marquage-recapture dans un contexte de méta-analyse. Dans le but d'évaluer la variabilité latitudinale de la croissance du listao (Katsuwonus pelamis) dans l'Atlantique Est, les données de marquage traditionnel collectées par l'ICCAT depuis le début des années soixante ont été reanalysées à l'aide d'une version modifiée du modèle de croissance de von Bertalanffy-Fabens. L'analyse des taux de recaptures par strates longitudinales montre que les échanges sont minima entre le Nord et le Sud au niveau de la latitude $10^{\circ} \mathrm{N}$. Etant donné qu'il est admis que les estimations des paramètres de la courbe de croissance $L_{\infty}$ et $K$ sont corrélées, nous proposons de substituer, dans l'équation de croissance, $L_{\infty}$ par une simple fonction bioénergétique de $K$ ajustée à partir des paramètres de croissance obtenus dans la littérature sur le sujet. La fonction de vraisemblance pour ces données de méta-analyse est combinée aux vraisemblances des deux jeux de données de marquage afin d'estimer $K$ de manière simultanée dans les deux régions, tout en conservant de manière correcte les incertitudes attachées à
\end{abstract}

\footnotetext{
${ }^{\text {a }}$ Corresponding author: gaertner@ird.fr
} 
chaque jeu de données. Nous montrons dans cette étude que les listaos qui vivent dans les eaux situées au Sud de la latitude $10 \circ \mathrm{N}$ peuvent atteindre des longueurs maximales plus élevées que ceux vivant dans le Nord mais avec un taux de croissance inférieur $\left(L_{\infty}=112,34 \mathrm{~cm}\right.$ contre $89,38 \mathrm{~cm}$, et $K=0,14$ contre 0,38 , respectivement). Nos estimations sont comprises dans la gamme de variation des paramètres de croissance reportés pour le listao dans l'Océan Atlantique et dans d'autres océans. Au contraire, les estimations de $L_{\infty}$ et de $K$ faites au Sénégal au début des années 1980 dans le cadre du Programme international « Année Listao », et utilisées traditionnellement par l'ICCAT, ne sont pas confirmées par notre étude. Ces résultats, relatifs à la plasticité phénotypique de la croissance du listao en fonction de la latitude, suggèrent de possibles différences régionales au niveau de la productivité du stock et en conséquence l'intérêt que représentent les méthodes d'évaluation des stocks non-conventionnelles, telles que des matrices de transition des prises par taille par régions, pour analyser les réponses du listao vis-à-vis de l'exploitation

\section{Introduction}

It is admitted that growth rate of skipjack tuna (Katsuwonus pelamis) depicts substantial differences according to the latitude in the Atlantic Ocean (Bard and Antoine 1986), as well as in the Pacific Ocean (Sibert et al. 1983; Bayliff 1988). There remains, however, considerable uncertainty about the variability of the growth parameters between areas and consequently the ICCAT Standing Committee on Research and Statistics (SCRS) considers that it is a priority to gain more knowledge on the growth patterns of this species.

Tag-recovery studies facilitate the collection of a variety of types of information on the species under study, such as stock structure, growth rate, gear selectivity, migrations, survival/mortality, immediate mortality due to tagging, etc. (Gaertner et Hallier 2004; Gaertner et al. 2004; Hallier et al. 2005). Consequently, conventional tagging is one of the research tools widely used by tuna commissions to increase the biological understanding of spatially structured populations and to gauge the effects of fishing activities on these populations. Between the early 1960s and 2002 a total of 35965 skipjacks were tagged with conventional "spaghetti" tags within the framework of different tagging programs conducted by ICCAT scientists with the collaboration of fishermen.

A re-analysis of the tagging data collected in the Senegalese area during the research program termed "Mattes Associées aux Canneurs" (MAC) (Hallier et al. 2001) showed that the parameters of the growth curve obtained in this region were closer to values estimated in the Gulf of Guinea or in other oceans (Hallier and Gaertner 2006) than those previously reported in Senegal (Cayré and Farrugio 1986). With the aim to reinforce previous findings and to explore whether the growth of skipjack exhibits phenotypic plasticity in different regions of the eastern Atlantic Ocean (i.e., longitude $<=30^{\circ} \mathrm{W}$ ) we explored the entire release-recovery information available into the ICCAT tagging database.

In this paper, (1) we take advantage of skipjack growth parameters estimated from existing studies in the world's oceans within a meta-analysis framework. Since von Bertalanffy's growth parameters $K$ and $L \infty$ are negatively correlated, existing growth information from numerous studies is used to expressed $L \infty$ as a bioenergetic function of $K$, whose equation is incorporated into the von Bertalanffy-Fabens growth model. (2) Instead of modelling northern and southern tagging data separately, we incorporate the three data sets into a combined likelihood to estimate simultaneously the two regional growth parameters $K$ conditional on all types of information.

\section{Material and methods}

Measurements of the fish were taken, with callipers, from the tip of the snout to the fork of the tail to the nearest centimetre or half-centimetre. Only fish with accurate size and known dates and positions at tagging and at recapture are used for growth study in the eastern Atlantic (i.e., excluding data with longitude $>=30^{\circ} \mathrm{W}$ longitude). From a subset of 4084 data, recaptures of fish at liberty for less than 30 days as well as fish with growth less than $-2 \mathrm{~cm}$ have been omitted (1356 fish). The first limitation is to 
take into account possible stress of the fish that will disrupt the growth and slight measurement errors as tuna were measured directly on the tagging cradle. The second limitation is directly related to measurement errors that can be done negatively or positively.

A comparative analysis of growth rates between different regions supposes low amounts of mixing. To assess the level of non-mixing between northern and southern regions, we developed a series of $2 * 2$ contingency tables of release-recapture per region, each corresponding to a particular latitude from $20^{\circ} \mathrm{N}$ latitude to $5^{\circ} \mathrm{S}$ latitude. The latitude for which the chisquare test of non-mixing (Latour et al. 2001) is the largest will be used to discriminate the tagging data into two geographic regions. Then, only nonmixed skipjacks (i.e., tagged and recovered in the same region) were analyzed.

Growth was modelled using the translation of the von Bertalanffy curve formalized by Fabens (1965) to account for the sort of information obtained from tagging programmes (i.e., tag release and recapture lengths and time at liberty data):

$$
\begin{aligned}
& \Delta L=\left(L_{\infty}-L_{t}\right)\left(1-e^{-K \Delta t}\right) \\
& \Delta L=L_{t+\Delta t}-L_{t}
\end{aligned}
$$

where the increment in length $\Delta L$ through the period $\Delta t$ (i.e., the time at liberty) is calculated as the difference between the size at recapture $L t+\Delta t$ and the size at tagging $L t ; K$ and $L_{\infty}$ are the conventional growth rate coefficient and the asymptotic average maximum length of the von Bertalanffy curve, respectively (Haddon 2001).

Assuming normal random errors, the likelihood function $L$ can be represented by:

$$
L=\prod\left(\frac{1}{\sigma \sqrt{2 \pi}} e^{-\frac{(\Delta L-\Delta \hat{L})^{2}}{2 \sigma^{2}}}\right)
$$

The maximum likelihood estimates of $L_{\infty}$ and $K$, are obtained by minimising the negative logarithm of $\mathrm{L}$ (LL), which is :

$$
L L=-\sum L n\left(\frac{1}{\sigma \sqrt{2 \pi}} e^{-\frac{(\Delta L-\Delta \hat{L})^{2}}{2 \sigma^{2}}}\right)
$$

where $\sigma$ is the standard deviation which can be obtained analytically (as in the present study) or estimated as a free parameter in the likelihood function.

This method is termed hereafter the conventional von Bertalanffy-Fabens method. However, it is generally admitted that (1) there is a high negative correlation between the estimates of $K$ and $L_{\infty}$ and (2) these estimates are sensitive to the size range of the population sampled. That is to say that from a sample composed mainly of young fish one can expect a reasonable estimate of $K$ and a weak estimate of $L_{\infty}$ (and vice versa). In the case of tagging data, methods to take into account the fact that the proportion of shortterm returns can be very large compared with the long-term returns of tagged fish have been proposed by Joseph and Calkins (1969). When there are some doubts, there is still the possibility to perform sensitivity 
analysis, e.g., fixing one parameter and calculating the objective function for different values of the second (Bayliff 1988) or, based on expert knowledge, fixing the asymptotic length at a value corresponding to an average maximum size observed in the catch (Bard and Antoine 1986). However, in such a situation Hilborn and Liermann (1998) highlighted the application of meta-analysis in order to summarize and to quantify variability of population parameters among numerous isolated studies.

For all of these reasons, we endorsed this approach by incorporating existing growth information in the tagging analysis within a meta-analysis approach based on Beverton and Holt's considerations about several patterns in growth and mortality parameters across fish species. Following these authors, Jensen (1997) stated that the relation between asymptotic length and the growth coefficient might occur as the result of a constraint on growth, and consequently can be expressed as a simple bioenergetic growth equation, such as:

$$
L_{\infty}=C K^{-h}
$$

where $C$ and $h$ represent metabolic and growth parameters whose interpretation is beyond the scope of this paper.

Although, these metabolic considerations were originally used for the comparison of life history parameters across species or across taxonomic groups, we considered that growth parameters of skipjack obtained from isolated studies reflect the variability across the different stocks of this species in the world's oceans (Table 1), and consequently may be useful to provide inferences on the parameters $C$ and $h$.

Substituting $L_{\infty}$ by this function of $K$, into the conventional Fabens' equation gives:

$$
\Delta L=\left(\left(C K^{-h}\right)-L_{t}\right)\left(1-e^{-K \Delta t}\right)
$$

One advantage of the likelihood theory is the possibility to integrate multiple types of data (Maunder 2001; Hallier et al. 2005). Assuming independence between the observations, the combined log likelihood of the three types of data is:

$L L=-\left[\sum_{j=1}^{2} \sum_{i=1}^{n j} L n\left(\frac{1}{\sigma_{j} \sqrt{2 \pi}} e^{-\frac{\left(\Delta L_{i j}-\Delta \hat{L}_{i j}\right)^{2}}{2 \sigma_{j}^{2}}}\right)+\sum_{l=1}^{n k} L n\left(\frac{1}{\sigma_{k} \sqrt{2 \pi}} e^{-\frac{\left(L_{\infty} l-\hat{L}_{\infty} l\right)^{2}}{2 \sigma_{k}^{2}}}\right]\right.$

where $j=1,2$ represents the tagging region, either the northern region or the southern region $(i=1, \ldots, n j$ with $n j=632$ and 629 fish in each region, respectively) and $k=$ the existing pairs of estimated growth parameters $K$ and $L_{\infty}$ (Table $1, l=1, \ldots, n k$ with $\left.n k=29\right)$.

The estimates of the growth parameters from the combined approach are compared with the growth estimates obtained by separately fitting the two tagging data sets from the conventional von Bertalanffy-Fabens model. Confidence intervals (95\% C.I.) of the parameters of interest were estimated by bootstrapping the residuals $(B=1000)$. It should be noted that other approaches that permit simultaneous quantitative analysis of growth, such as Bayesian methods, have also been proposed for estimating variability among individuals (Pilling et al. 2002) or among populations within a species (Helser et al. 2007). 
Table 1. Estimates of growth parameters from isolated studies for skipjack in the world's oceans used for modelling the bioenergetic function expressing $L_{\infty}$ as a function of $K$ used into the integrated approach.

\begin{tabular}{|c|c|c|c|c|}
\hline Area & $L_{\infty}$ & $K$ & Method & Reference \\
\hline E. Atlantic G. of Guinea & 80 & 0.32 & Tagging & Bard and Antoine, 1986 \\
\hline E. Atlantic N. trop & 80 & 0.60 & Tagging & Bard and Antoine, 1986 \\
\hline E. Atlantic G. of Guinea & 86.7 & 0.31 & Spines & Chur and Zharov, 1983 \\
\hline E. Atlantic Senegal & 62 & 2.08 & Tagging & Cayré et al, 1986 \\
\hline E. Atlantic Cap Vert & 60 & 1.54 & Tagging & Cayré et al, 1986 \\
\hline E. Atlantic Senegal & 97.26 & 0.25 & Tagging & Hallier and Gaertner, 2006 \\
\hline W. Atlantic Caribbean sea & 94.9 & 0.34 & Length-freq & Pagavino and Gaertner, 1995 \\
\hline W. Atlantic Brasil & 87.12 & 0.22 & Spines & Vilela and Costello, 1991 \\
\hline Indian Ocean & 60.6 & 0.93 & Length-freq & Marcille and Stequert, 1976 \\
\hline Indian Ocean Maldives & 64.3 & 0.55 & Tagging & Adams, 1999 \\
\hline Indian Ocean Maldives & 82 & 0.45 & Length-freq & Hafiz, 1987, in Adams 1999 \\
\hline Indian Ocean Sri Lanka & 85 & 0.62 & Length-freq & Amarasiri and Joseph, 1987 \\
\hline Indian Ocean Sri Lanka & 77 & 0.52 & Length-freq & Sivasubramanium, 1985; in Adams, 1999 \\
\hline Indian Ocean Minicoy & 90 & 0.49 & Length-freq & Mohan and Kunhikoya, 1985; in Adams, 1999 \\
\hline E. Pacific & 75.5 & 0.77 & Tagging & Sibert et al, 1979 \\
\hline E. Pacific & 79 & 0.64 & Tagging & Josse et al, 1979 \\
\hline E. Pacific $N$ & 96.3 & 0.52 & Tagging & Bayliff, 1988 \\
\hline E. Pacific $\mathrm{S}$ & 66.5 & 1.81 & Tagging & Bayliff, 1988 \\
\hline E. Pacific & 73 & 0.82 & Tagging & Joseph and Calkins, 1969 \\
\hline E. Pacific & 107 & 0.42 & Length-freq & Joseph and Calkins, 1969 \\
\hline W. Pacific & 61.3 & 1.25 & Tagging & Sibert et al, 1979 \\
\hline W. Pacific & 65.5 & 0.95 & Tagging & Josse et al, 1979 \\
\hline W. Pacific Vanuatu & 60 & 0.75 & Length-freq & Brouard et al, 1984 \\
\hline W. Pacific Trop. \& Jap. & 93.6 & 0.43 & Otolith & Tanabe et al, 2003 \\
\hline W. Pacific Japan & 76.6 & 0.60 & Length-freq & Yao, 1981; in Wild and Hampton, 1994 \\
\hline W. Pacific Taiwan & 103.6 & 0.30 & Vertebrae & Chi and Yang, 1973; in Wild and Hampton, 1994 \\
\hline Central Pacific & 102.2 & 0.55 & Otolith & Uchiyama and Struhsaker, 1981 \\
\hline Central Pacific & 80 & 0.95 & Grouped L-freq & Brock, 1954; in Adams, 1999 \\
\hline Central Pacific West & 74.8 & 0.52 & Length-freq & Wankowski, 1981 \\
\hline
\end{tabular}

\section{Results}

Tagging data were examined by latitude to investigate whether skipjacks were more likely recaptured in the region of their release. The calculated $\chi^{2}$ statistics depict a maximum value at $10{ }^{\circ} \mathrm{N}$ latitude which can be considered as the latitude which maximizes the non-mixing between the northern and southern regions in the eastern Atlantic Ocean (Fig. 1). On the 2409 skipjacks released North of $10^{\circ} \mathrm{N}$ latitude, only 36 (i.e., $1.5 \%$ ) were recaptured in the South and no fish tagged in the South was recaptured in the northern region (Table 2).

Table 2. Contingency table for the released-recaptured skipjack separated by $10^{\circ} \mathrm{N}$ latitude in the eastern Atlantic Ocean.

\begin{tabular}{lccc}
\hline & & $\begin{array}{c}\text { Captured at } \\
\text { Lat }>=10^{\circ} \mathrm{N}\end{array}$ & $\begin{array}{c}\text { Captured at } \\
\text { Lat }<10^{\circ} \mathrm{N}\end{array}$ \\
\hline Released at & Observed & 2373 & 36 \\
Lat $>=10^{\circ} \mathrm{N}$ & Expected & 1484.4 & 924.6 \\
Released at & Observed & 0 & 1442 \\
Lat $<10^{\circ} \mathrm{N}$ & Expected & 88.6 & 553.4 \\
& & & \\
\hline
\end{tabular}


The ranges of lengths at release are approximately similar for the two regions considered (i.e., $42-$ $60 \mathrm{~cm}$ FL for latitudes north of $10^{\circ} \mathrm{N}$ latitude, and 36-62 cm for equatorial areas; Fig. 2). First, with the aim of comparing the different approaches, growth curves were fitted separately to each region with the use of the conventional von Bertalanffy-Fabens method. Conventional regression diagnostic plots were used to identify outliers and influential observations and then the tagging data in each geographic set were fitted again with outliers removed. The estimates of the asymptotic length $\left(L_{\infty}\right)$, the growth rate coefficient $(K)$ and the corresponding bootstrapped C.I. are shown in Table 3.

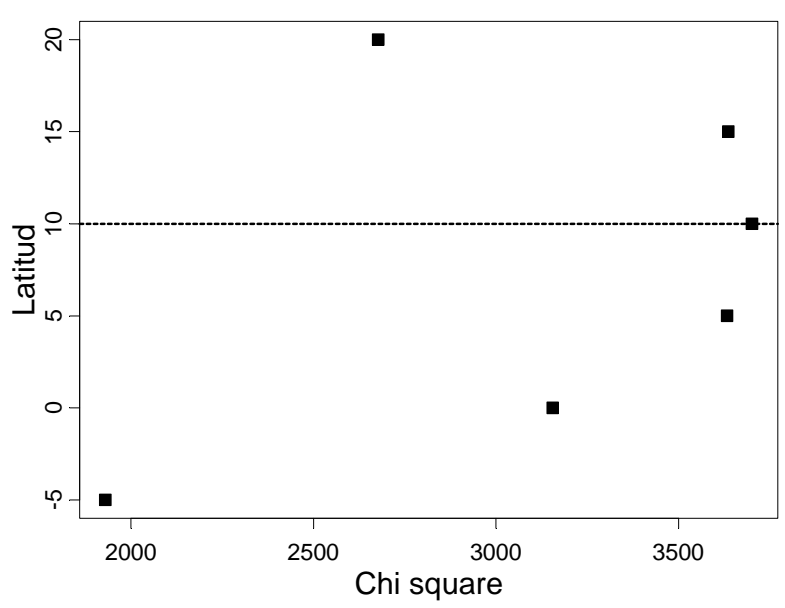

Fig. 1. Application of the $\chi^{2}$ test to $2 * 2$ contingency tables of release-recaptures per region to explore the latitude which maximizes the non-mixing rate of skipjack between the North and the South in the eastern Atlantic.
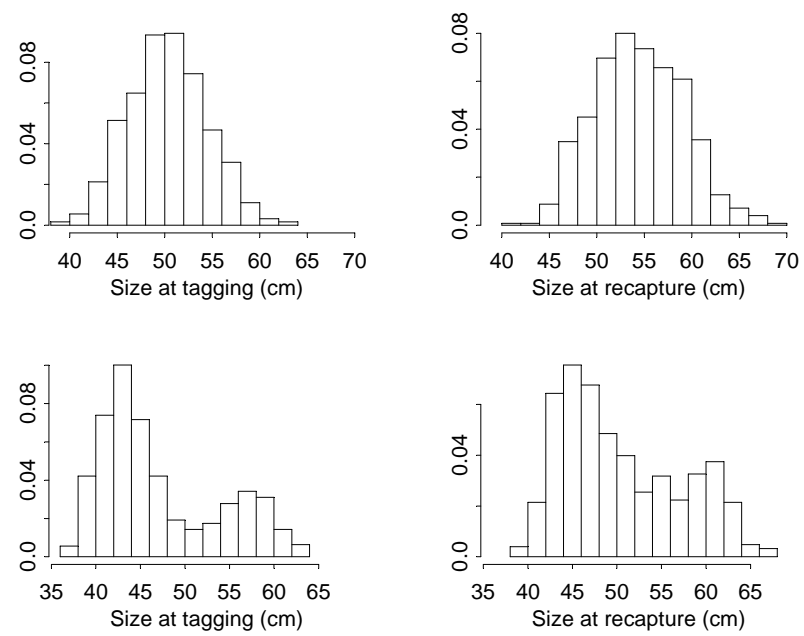

Fig. 2. Frequency of recoveries for different lengths at release (left panel) and lengths at recapture (right panel) for eastern Atlantic skipjack tagged and recaptured at latitudes $>10^{\circ} \mathrm{N}$ latitude (upper panel) or at latitudes $<=10^{\circ} \mathrm{N}$ latitude (lower panel).

The asymptotic average maximum length of the von Bertalanffy curve appears very similar between fish tagged and recovered at latitudes more northern than $10^{\circ} \mathrm{N}$ latitude and fish tagged and recovered in more southern areas $(96.78 \mathrm{~cm}$ vs. $99.88 \mathrm{~cm}$, respectively). However, the difference in the growth rate coefficients ( 0.35 vs. 0.20 per year) suggests that skipjack grow faster in the northern region of the eastern Atlantic Ocean than in the equatorial areas. Support for the latitudinal gradient in growth is reinforced by the results obtained from the combined likelihood ( 0.38 vs. 0.14 per year, Table 3$)$.

The corresponding value of the asymptotic length $L_{\infty}(89.38 \mathrm{~cm}$, and $112.34 \mathrm{~cm}$, respectively) are calculated a posteriori based on the estimated parameters $C(71.81)$ and $h(0.22)$ of the bioenergetic function relating $L_{\infty}$ and $K$ which is embedded into the combined likelihood (Fig. 3). It must be stressed that both the conventional and the combined methods provided a similar finding (i.e., slower growth rate in the South), but bootstrapped confidence intervals of $K$ were substantially narrower for the integrated method (Fig. 4). 
Table 3. Summary of bootstrapped statistics for the von Bertalanffy-Fabens model per region and for the integrated likelihood approach combining the two eastern Atlantic regional tagging data and the metaanalysis on existing studies on growth parameters of skipjack in the world's oceans. ${ }^{*}=$ estimated $a$ posteriori based on the $C$ and $h$ estimates of the bioenergetic function relating $L_{\infty}$ at $K$; NA $=$ non estimable.

\begin{tabular}{|c|c|c|c|c|c|c|}
\hline Method & Area & Estimate & $K$ & $L_{\infty}$ & $C$ & $h$ \\
\hline \multirow{7}{*}{ Fabens } & \multirow{3}{*}{ North } & mean & 0.35 & 96.78 & NA & NA \\
\hline & & median & 0.35 & 91.82 & NA & NA \\
\hline & & C.I. & $0.14-0.56$ & $76.96-145.35$ & NA & NA \\
\hline & \multirow{4}{*}{ South } & & & & & \\
\hline & & mean & 0.20 & 99.88 & NA & NA \\
\hline & & median & 0.22 & 85.00 & NA & NA \\
\hline & & C.I. & $0.07-0.34$ & $72.49-167.13$ & NA & NA \\
\hline \multirow{7}{*}{ Integrate } & \multirow{3}{*}{ North } & mean & 0.38 & $89.38^{*}$ & 71.81 & 0.22 \\
\hline & & median & 0.37 & $89.10^{*}$ & 71.78 & 0.22 \\
\hline & & C.I. & $0.28-0.53$ & $78.18-99.89$ & $66.74-76.41$ & $0.15-0.29$ \\
\hline & \multirow{4}{*}{ South } & & & & & \\
\hline & & mean & 0.14 & $112.34 *$ & 71.81 & 0.22 \\
\hline & & median & 0.14 & 111.08* & 71.78 & 0.22 \\
\hline & & C.I. & $0.10-0.18$ & $96.07-134.35$ & $66.74-76.41$ & $0.15-0.29$ \\
\hline
\end{tabular}

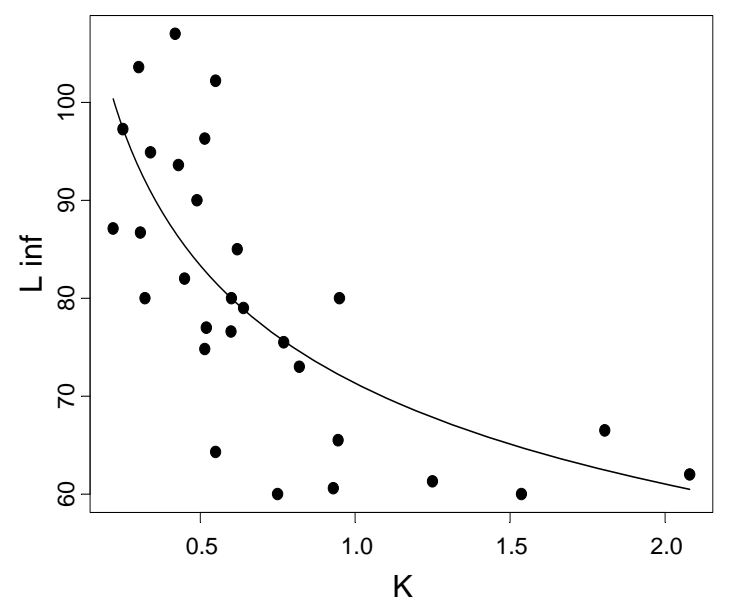

Fig. 3. Distributions of skipjack growth parameters $L_{\infty}$ and $K$ estimated from existing studies in the world's oceans (see, Table 1) and fitted values (solid line) of the Jensen's bioenergetic function from the integrated likelihood approach.
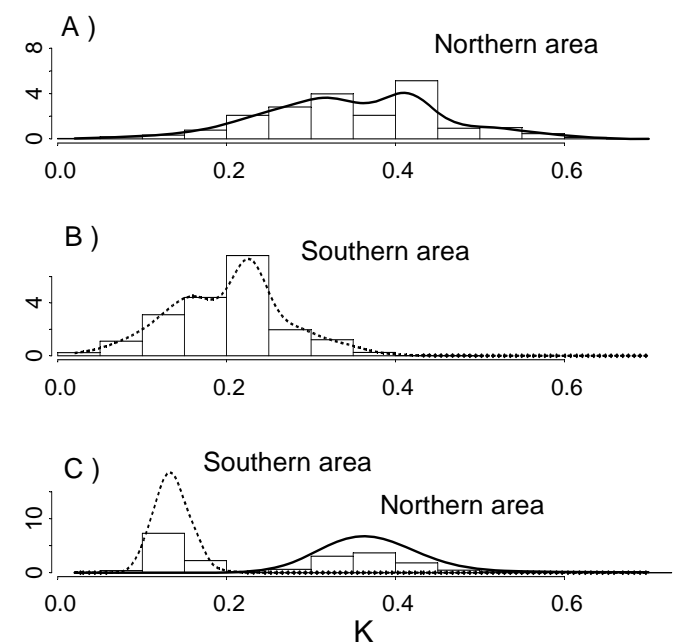

Fig 4. Bootstrapped values of the growth parameter $K$ for eastern Atlantic skipjack based on the conventional von Bertalanffy-Fabens model fitted separately for fish tagged and recaptured either North of $10^{\circ} \mathrm{N}$ latitude (A), or South (B), and based on the integrated likelihood approach combining the two tagging data sets and the meta-analysis on existing studies on growth parameters in the world's oceans $(\mathrm{C})$. 


\section{Discussion and conclusion}

In the present analysis, rather than ignoring everything ever learnt from previous growth studies, we summarized all the information contained in the historic data set into the functional relationship between growth parameters for different stocks of skipjack. It must be noted that fitting different tagging data separately makes the assumption that there is no relationship among the growth parameters of the populations under study which, in light of previous analyses, seems unrealistic. In contrast, (1) accounting for plausible growth parameters values within a meta-analysis framework has the advantage of borrowing strength from other populations to improve parameter estimation for a given population with weaker data (Hilborn and Liermann 1998); and (2) integrating these data into a combined likelihood reduces the loss of information and the risk that uncertainty be inadequately transferred between the different equations (Maunder 2001).

Our results are in agreement with the estimates of the growth parameters obtained from skipjacks tagged during the MAC activities in the Senegalese area (Hallier and Gaertner 2006), in the Gulf of Guinea (Chur and Zharov 1983; Bard and Antoine 1986), in the western Atlantic (Vilela and Castello 1991; Pagavino and Gaertner 1995), as well as in other parts of the world's oceans. In contrast, we found substantial differences in the growth parameters between the present study and the estimates reported by Cayré et al. (1986) for the Senegalese region (62 $\mathrm{cm}$ for $L \infty$ and 2.080 for $K$; Table 1).

The fact that growth parameters of skipjack may vary with latitude has been pointed out several authors (Bard and Antoine 1986; Bayliff 1988, among others). Our findings suggest that skipjack inhabiting waters south of $10^{\circ} \mathrm{N}$ latitude can generally be expected to grow larger but at a slower rate than skipjack inhabiting North of $10^{\circ} \mathrm{N}$ latitude.

Since conventional tagging data do not provide detailed information on the migratory behaviour of the fish when they are at liberty, integrating environmental indicators with conventional tagging data to infer habitat of tropical tuna remains uncertain. That is that individual migrations are more complex than directed movements with straight trajectories, and consequently the residence time within a specific area between the location at release and the location at recapture is unknown. In addition, one can argue that movements of skipjack are not constrained by surface water environmental factors within the geographic confines of their distribution. However taking these limitations into account, a comparison was made of the average physical environmental factors (i.e., sea surface temperature, dissolved oxygen and salinity) between each area from oceanographic data of the World Ocean Database 2005 (NODC ${ }^{b}$ ) (Table 4).

Even if skipjack do penetrate into cooler waters of thermocline as deep as $200 \mathrm{~m}$, laboratory and field studies indicate that skipjack can live in a wide range of water temperatures $\left(20-29{ }^{\circ} \mathrm{C}\right)$, and that only fish less than $1 \mathrm{~kg}$ can tolerate temperatures over $30^{\circ} \mathrm{C}$. The range of sea surface temperatures observed in both regions coincides with these values and consequently there is no evidence that growth is temperature limited in the area South of $10^{\circ} \mathrm{N}$ latitude. Dissolved oxygen concentration may be a limiting factor for skipjack, specifically at concentrations below $2.8 \mathrm{ml} \mathrm{L}^{-1}$, and would confine the fish to fairly shallow layers in some tropical areas. Evans et al. (1981) showed that a combination of an $18{ }^{\circ} \mathrm{C}$ isotherm and depth contours of the $3.5 \mathrm{ml} \mathrm{L}^{-1}$ dissolved oxygen surface was considered as a proxy of skipjack habitat depth to hypothesize areas of vulnerability of skipjack to surface gears in the Atlantic Ocean. Based on this approach, and bearing in mind that oxygen requirements may vary with fish size, skipjack habitat depth is greater in the southern region than in the $10^{\circ} \mathrm{N}$ latitude region. Since fish growth faster in

\footnotetext{
${ }^{\mathrm{b}} 1$ National Oceanographic Data Center, NOAA http://www.nodc.noaa.gov/OC5/WOD05/pr_wod05.html
} 
the northeastern Atlantic, the restriction of habitat suitable for skipjack in this region does not negatively affect its growth rate.

Table 4. Summary statistics for the environmental factors in both areas considered in the analysis (from the World Ocean Database 2005, NODC; period: 1980-2005). The limits of latitude and longitude for each region contain $90 \%$ of the tagging at release and at recapture. ${ }^{*}$ To minimize the effect of seasonality in the northern region, environmental data were restricted to May-November, i.e., the period of the year which represents $90 \%$ of the released-recaptured fish.

\begin{tabular}{clccc}
\hline Area & $\begin{array}{l}\text { Latitude } / \\
\text { Longitude }\end{array}$ & $\begin{array}{c}\text { Temperature }\left({ }^{\circ} \mathrm{C}\right) \\
(90 \% \text { C.I. })\end{array}$ & $\begin{array}{c}\text { Salinity (\%o) } \\
(90 \% \text { C. I. })\end{array}$ & $\begin{array}{c}\text { Dissolved Oxygen (ml/l) } \\
(90 \% \text { C. I. })\end{array}$ \\
\hline North* & $28^{\circ} \mathrm{N}-14^{\circ} \mathrm{N}$ & 20.2 & 36.3 & 5.1 \\
& $19^{\circ} \mathrm{W}-16^{\circ} \mathrm{W}$ & $(17.8-24.6)$ & $(35.9-36.8)$ & $(4.5-5.8)$ \\
South & $5^{\circ} \mathrm{N}-3^{\circ} \mathrm{S}$ & 26 & 35.1 & 4.6 \\
& $12^{\circ} \mathrm{W}-8^{\circ} \mathrm{E}$ & $(22.6-29.1)$ & $(32.3-35.9)$ & $(4.5-5.3)$ \\
\hline
\end{tabular}

Regarding the productivity of the two regions considered, and their respective richness in tuna forage, there is evidence that surface waters of the northern region are strongly enriched with nutrients by wind-induced upwellings off the Senegalese and Mauritanian coasts. However, in a non-tropical upwelling situation (such as the Mauritania area), the rich forage should attract tunas but the low temperatures may exclude them (Sund et al. 1981). During the winter months, when surface temperatures are below $20^{\circ} \mathrm{C}$, skipjack can only reach the fringes of the concentration of their prey. As the upwelling regime decays, the food-rich areas become warm enough for the tunas to penetrate them. This period of transition corresponds, in effect, to the start of the fishing season (approximately May in Senegal and June in Mauritania; Stretta 1988). On the other hand, the southern area is under the influence of numerous physical processes that may enrich near-surface waters with nutrients in different places and periods of the year: the Ghanaian upwelling and the equatorial upwelling (both in July- September), the vertical mixing over a ridge in the thermocline along the North Equatorial Countercurrent (January-February) and, for the eastern-most waters of this region, the proximity of the Cape Lopez front. Even if movements into relatively productive areas may have survival value for tunas, and the fact that they probably aggregate around any rich patches of food that they find in waters of suitable temperature and dissolved oxygen (Sund et al. 1981), it is unclear how to relate the food available in a given area to tunas' food requirements and finally to their growth rate.

Whatever the environmental factors affecting the growth of skipjack, two conclusions can be made from our study: (1) the growth parameters for the two groups of skipjack separated by $10^{\circ} \mathrm{N}$ latitude could differ as much as $23 \mathrm{~cm}$ and 0.24 per year for $L_{\infty}$ and $K$, respectively; and (2) because of growth correlation to other life history parameters (e.g., size at first maturity and mortality) one can expect substantial differences in fish population productivity. This feature and certain other key aspects of its biology (e.g., opportunistic spawning throughout the year, and over large areas, resulting in widespread recruitment but heterogeneous in space and time; Cayré and Farrugio 1986) make it difficult to conduct an assessment using current methods. As catch-at-age matrix would not be consistent because fish of the same age can exhibit different sizes depending on their past movement patterns, catch-at-size analysis and a growth-transition matrix by large geographical entities could be an alternative to assess the status of skipjack stocks. 


\section{References}

Adams M.S., 1999, Population Dynamics and Assessment of Skipjack Tuna (Katsuwonus pelamis) in the Maldives. PhD dissertation, Renewable Resources Assesment Group. Centre for Environmental Technology, T.H. Huxley School of Environment, Earth Sciences and Engineering, Imperial College of Science Technology and Medicine, Univ. of London.

Amarasiri C., Joseph L., 1987, Skipjack tuna (Katsuwonus pelamis) - aspects on the biology and fishery from the western and southern coastal waters of Sri Lanka. IPTP. Coll. Vol. Work. Doc. 2, 1-10.

Bard F.X., Antoine L., 1986, Croissance du listao dans l'Atlantique Est. In: Symons P.E.K., Miyake P.M., Sakagawa G.T. (Eds.), Proc. ICCAT conference on the international skipjack year program, Madrid, pp. 301-308.

BayliffW.H., 1988, Growth of skipjack, Katsuwonus pelamis and yellowfin, Thunnus albacares, tunas in the Eastern pacific Ocean, as estimated from tagging data. Inter-Am. Trop. Tuna Comm. Bull.19, 311-358.

Brock V.E., 1954, Some aspects of the biology of the aku (Katsuwonus pelamis) in the Hawaiian Islands. Pac. Sci. 8, 94-104.

Brouard F., Grandperrin R., Cillaurren E., 1984, Croissance des jeunes thons jaunes (Thunnus albacares) et des bonites (Katsuwonus pelamis) dans le Pacifique tropical occidental. ORSTOM de Port-Vila, Notes Doc. Océanogr. 10.

Cayré P., Diouf T., Fonteneau A., 1986, Analyse des données de marquages et recaptures de listao (Katsuwonus pelamis) réalisés par le Sénégal et la République du Cap-Vert. In: Symons P.E.K., Miyake P.M., Sakagawa G.T. (Eds.), Proc. ICCAT conference on the international skipjack year program, Madrid, pp. 309-316.

Cayré P., Farrugio H., 1986, Biologie de la reproduction du listao (Katsuwonus pelamis) de l'océan Atlantique. In: Symons, P.E.K., Miyake, P.M., Sakagawa, G.T. (Eds.), Proc. ICCAT conference on the international skipjack year program, Madrid, pp. 252-272.

Chi K.S., Yang, R.-T., 1973, Age and growth of skipjack tuna in the waters around the southern part of Taiwan. [Summ. in Chin.] Nat. Taiwan Univ. Sci. Rep. Acta Oceanogr. Taiwanica 3, 199-221.

Chur V.N., Zharov, V.L., 1983, Determination of age and growth of the skipjack tuna, Katsuwonus pelamis (Scombridae) from the southern part of the Gulf of Guinea. J. Ichthyol. 23, 53-67.

Evans R.H., McLain D.R., Bauer R.A., 1981, Atlantic Skipjack Tuna: Influences of mean environmental conditions on their vulnerability to surface fishing gear. Mar. Fish. Rev. 43, 1-11.

Fabens A.J., 1965, Properties and fitting of the von Bertalanffy growth curve. Growth 29, 265-289.

Gaertner D., Hallier J.P., 2004, Combining Bayesian and simulation approaches to compare the efficiency of two types of tags used in tropical tuna fisheries. Aquat. Living Resour. 17, 175-183

Gaertner D., Hallier J.P., Maunder M.N., 2004, A tag attrition model as a means to estimate the efficiency of two types of tags used in tropical tuna fisheries. Fish. Res. 69, 171-180.

Haddon M., 2001, Modelling and quantitative methods in fisheries. Chapman and Hall/CRC, Boca Raton.

Hafiz A., 1987, Skipjack fishery in the Maldives. IPTP. Coll. Vol. Work. Doc. 2, 11-22.

Hallier J.P., Gaertner D., 2006, Estimated growth rate of the Skipjack tuna (Katsuwonus pelamis) from tagging surveys conducted in the Senegalese area (1996-1999) within a meta-analysis framework Col. Vol. Sc. Pap. ICCAT 59, 411-420.

Hallier J.P., Diouf T., Hervé A, Peignon C., 2001, Le Programme MAC: Etat des opérations et des analyses. Doc. multigraphié, CRODT, IRD, CNROP.

Hallier J.P., Stequert B., Maury O., Bard F-X., 2005, Growth of bigeye tuna (Thunnus obesus) in the Eastern Atlantic ocean from tagging-recapture data and otolith readings. 2nd World Meeting on Bigeye tuna, Col. Vol. Sci. Pap. ICCAT 57, 181-194.

Helser T.E., Stewart I.J., Lai H-L., 2007, A Bayesian hierarchical meta-analysis of growth for the genus Sebastes in the eastern Pacific Ocean. Can. J. Fish. Aquat. Sci. 64, 470-485.

Hilborn R., Liermann M., 1998, Standing on the shoulders of giants: learning from experience in fisheries. Rev. Fish Biol. Fish. 8, 273-283. 
Jensen A.L., 1997, Origin of the relation between $K$ and $\operatorname{Linf}$ and synthesis of relations among life history parameters. Can. J. Fish. Aquat. Sci. 54, 987-989.

Joseph J., Calkins T.P., 1969, Population dynamics of the skipjack tuna Katsuwonus pelamis of the Eastern Pacific Ocean. Bull. Inter. Am. Trop. Tuna Comm. 13.

Josse E., Le Guen J.C., Kearney R., Lewis A., Smith A., Marec L., Tomlinson P.K., 1979, Growth of skipjack. South Pacific Commission, Noumea, Occas. Pap. 11.

Latour R.J., Hoenig J.M., Olney J.E., Pollock K.H., 2001, A simple test for nonmixing in multiyear tagging studies: Application to striped bass tagged in the Rappahannock river, Virginia. Trans. Am. Fish. Soc. 130, 848-856.

Marcille J., Stéquert B., 1976, Etude préliminaire de la croissance du listao (Katsuwonus pelamis) dans l'ouest de l'océan Indien tropical. Cah. ORSTOM Sér. Océanogr. 14, 139-151.

Maunder M.N., 2001, A general framework for integrating the standardization of catch per unit of effort into stock assessment models. Can. J. Fish. Aquat. Sci. 58, 795-803.

Mohan M., Kunhikoya K.K., 1985, Age and growth of Katsuwonus pelamis (Linnaeus) and Thunnus albacares (Bonnaterre) from Minicoy waters, In: Silas E.G (Ed.) Tuna Fisheries of the Exclusive Economic Zone of India: Biology and Stock Assessment 36, CMFRI 143.

Pagavino M., Gaertner D., 1995, Ajuste de una curva de crecimiento a frecuencias de tallas de atun listado (Katsuwonus pelamis) pescado en el Mar Caribe suroriental. Col. Vol. Sci. Pap. ICCAT 44, $303-$ 309.

Pilling G.M., Kirkwood G.P., Walker S.G., 2002, An improved method for estimating individual growth variability in fish, and the correlation between von Bertalanffy growth parameters. Can. J. Fish. Aquat. Sci. 59, 424-432.

Sibert J.R., Kearney R.E., Lawson T.A., 1983, Variation in growth increments of tagged skipjack Katsuwonus pelamis. Tuna and Billfish Assessment Programme. South Pacific Commission, Noumea, Tech. Rep. No. 10.

Sivasubramaniam K., 1985, Tunas and their fishery in the EEZs of Maldives and Sri Lanka. BOBP/WP/31, Bay of Bengal Programme (BOBP), Madras.

Stretta J.M., 1988, Environnement et pêche thonière en Atlantique tropical oriental. In: Fonteneau A., Marcille J. (Eds.) Ressources, pêche et biologie des thonidés tropicaux de l'Atlantique CentreEst. FAO Doc. Tech. Pêches No 292.

Sund P.N., Blackburn M.,Williams F., 1981, Tunas and their environment in the Pacific Ocean: A review. Oceanogr. Mar. Biol. Ann. Rev. 19, 443-512.

Tanabe T., Kayama S., Ogura M., 2003, An outline of the growth study on skipjack tuna (Katsuwonus pelamis) in the Western Pacific. Doc. IOTC WPTT-03-17.

Uchiyama J.H., Struhsaker P., 1981, Age and growth of skipjack tuna Katsuwonus pelamis, and yellowfin tuna, Thunnus albacares, asindicated by daily growth increments of sagittae. Fish. Bull. 79, 151162.

Vilela M.J.A., Castello J.P., 1991, Estudio de la edad y del crecimiento del barrilete Katsuwonus pelamis, en la region Sur y Sudeste de Brasil. Frente Marit. 9, 29-35.

Wankowski J.W.J., 1981, Estimated growth of surface schooling skipjack tuna, Katsuwonus pelamis, and yellowfin tuna, Thunnus albacares, from the Papua New Guinea Region. Fish. Bull. 79, 517-532.

Wild A., Hampton, J., 1994, A review of the biology and fisheries for skipjack tuna, Katsuwonus pelamis, in the Pacific Ocean. FAO Fish. Tech. Pap. 336, No. 2.

Yao M., 1981, Growth of skipjack tuna in the western Pacific Ocean. Bull. Tohoku Reg. Fish. Res. Lab. $43,71-82$. 